\title{
Seed orchard management and cultural options for quality seed production
}

\author{
Foreword \\ by G.-É. Caron ${ }^{1}$, R. Smith ${ }^{2}$ and D. Kolotelo ${ }^{3}$
}

The Tree Seed Working Group (TSWG) of the Canadian Tree Improvement Association/Association canadienne pour l'amélioration des arbres (CTIA/ACAA) was officially recognized in 1983 at the 19th CTIA/ACAA meeting. The mandate of the TSWG is to promote and facilitate the exchange of information among scientists and practitioners involved in all aspects of tree seed science and technology. To join the TSWG requires only an expressed interest in any area of forest tree seeds. Membership currently stands at about 300 . Included in this number are some 40 educational, research, or industrial institutions. As of 1992, 86\% of members resided in Canada (see H.O. Schooley 1993, For. Chron. 69: 650-651).

The TSWG tries to foster information exchange using four principal means:

1) Arranging for a Tree Seed Workshop at each biennial CTIA/ACAA meeting;

2) Issuing a NewsBulletin twice a year;

3) Supporting the activities of two subgroups:

1) Cone and Seed Insect Working Party

2) Tree Seed Processing and Testing Working Party;

4) Encouraging the membership, as individuals, to voice support for tree seed work through the Group's research and technology activities in a multiple of ways.

More recently, the group started an e-mail discussion group on the Internet (see TSWG NewsBulletin No. 21, 1994), thereby giving the TSWG worldwide exposure.
Workshops and technical sessions related to forest tree seed have been organized at every biennial CTIA/ACAA since 1983. Topics of these workshops have included "Maximizing the production and efficient use of improved seed", "Cone and seed insect pests", "Cone and seed crop monitoring", "Cone induction: response to practice", "Crown management", "Seed processing and testing".

These workshops are normally a half-day in duration and are incorporated into the program of the regular CTIA/ACAA meeting. The responsibility for organizing these workshops usually fell to the TSWG Chairman. However, in 1995, for the first time, a local organizer was appointed. Dave Kolotelo was the first candidate in 1995, and Stephan Mercier (Ministère des Ressources naturelles du Québec) has agreed to take on that responsibility for the upcoming TSWG Workshop to be held in Quebec City in 1997.

The most recent TSWG Workshop was held in Victoria, BC, 28 August 1995, and was titled "Seed orchard management and cultural options for quality seed production". Presentations at the workshops are usually voluntary, with the only selection criterion being that the topic generally meets the selected theme for the meeting. However, in 1995, James Barnett from the US Forest Service was an invited speaker.

\footnotetext{
${ }^{1}$ Chairman, Tree Seed Working Group, 1991 - present, École de sciences forestières, Université de Moncton, Edmundston, NB.

${ }^{2}$ Editor, Tree Seed Working Group NewsBulletin, and facilitator for the TREESEED internet discussion group, 1995 - present, Canadian Forest Service, Atlantic Region, Fredericton, NB.

${ }^{3}$ Coordinator of the TSWG Workshop, Victoria, BC 1995, and Coordinator of the Tree Seed Processing and Testing Working Party (1993 - present), BC Ministry of Forests, Tree Seed Center, Surrey, BC.
} 